\title{
Peran Guru BK Dalam Menangani Prilaku Membolos Siswa Di MTs Nu Raudlatus Shibyan
}

\author{
Muhammad Dafiq Dhiya'ul Haq \\ Institut Agama Islam Negeri Kudus, Jawa Tengah, Indonesia \\ dfdafiq@gmail.com
}

\begin{abstract}
Abstrak
Membolos merupakan perilaku tidak baik yang dilakukan oleh siswa seperti tidak masuk sekolah tanpa izin, tidak masuk jam pelajaran tertentu, pulang pada saat jam sekolah belum selesai. Penelitian ini bertujuan untuk mengetahui apa saja yang menyebabkan siswa melakukan perilaku membolos dan akibat dari perilaku membolos siswa di MTs NU Raudlatus Shibyan. Seperti yang sudah diketahui bahwa dampak dari perbuatan perilaku membolos adalah mengalami kegagalan dalam pembelajaran. Dalam penelitian ini metode penelitian yang digunakan adalah metode deskriptif kualitatif. Dari penelitian yang dilakukan memperoleh hasil bahwa perilaku membolos dipengaruhi oleh faktor internal dan eksternal, seperti motivasi dan minat belajar yang kurang, kenakalan remaja, dipengaruhi oleh teman yang suka bolos, tidak suka pada pelajaran dan guru tertentu. Akibat dari perilaku membolos yaitu sering mendapat panggilan dari guru BK, dan ketinggalan pelajaran sehingga mengakibatkan nilai turun, atau yang paling fatal yaitu dikeluarkan dari sekolah.
\end{abstract}

Kata kunci: Perilaku Membolos, Faktor Internal, Faktor Eksternal

\begin{abstract}
The Role of The Guidance and Counseling Teacher In Handling The Private Vocational School of Students At MTs Nu Raudlatus Shibyan. Truancy is bad behavior by students, such as not entering school without permission, not entering certain class hours, returning home when school hours have not finished. This study aims to determine what causes students to practice truancy and the consequences of truant behavior at MTs NU Raudlatus Shibyan. As is
\end{abstract}


well known, the impact of truancy is experiencing failure in learning. In this research, the research method used is descriptive qualitative method. From the research conducted, it is found that truancy behavior is influenced by internal and external factors, such as lack of motivation and interest in learning, juvenile delinquency, influenced by friends who like truant, dislike certain lessons and teachers. The result of truancy is that they often receive calls from counseling teachers, and miss lessons, resulting in lower grades, or the most fatal is being expelled from school.

Keywords: Truancy Behavior, Internal Factors, External Factors

\section{A. Pendahuluan}

Pendahuluan terdiri dari latar belakang yang memuat teori pendukung yang jelas, perumusan masalah, dan tujuan penulisan ditulis dalam satu bab tanpa sub judul. Pendahuluan memuat 3 - 5 paragraf dimana satu paragraf harus memuat paling tidak 300 kata, mengacu pada beberapa pustaka yang menjadi landasan teori atau alasan penelitian. Sajikan kajian teori dengan font Cambria (Headings) ukuran 12pt spasi 1,5.

Sekolah merupakan sebuah lembaga yang di peruntukan sebagai tempat pengajaran siswa atau murid di bawah bimbingan seorang guru.Sekolah memiliki pengaruh yang signifikan bagi remaja dan anak-anak.Berangkat ke sekolah teruntuk remaja merupakan suatu hak dan kewajiban sebagai sarana mengenyam pendidikan untuk meningkatkan kehidupan yang layak dan lebih baik.Namun yang patut di sayangkan adalah banyak remaja yang melakukannya tanpa ada alasan yang rasional. Banyak yang akhirnya melakukan membolos di jam pelajaran.Hal ini jelas jelas mencoreng nama besar dari lembaga pendidikan itu sendiri, namun tidak hanya di kota-kota besar saja yang melakukan tindakan membolos tapi juga sekolah-sekolah di daerah pun mengalami hal yang sama. Bahkan ada sebagian siswa yang mempunyai anggapan bahwa bolos adalah kegiatan yang fun dan mereka membolos bukan tanpa tujuan mereka bermain di tempat rental PS (playstation) dan mereka juga bermain game online di warnet sampe berjam-jam dan mengorbankan pelajaran dan tak sedikit juga yang membolos karena terbawa oleh teman-temanya yang mempunyai kecenderungan membolos dan juga ada 
anggapan bahwa mereka tidak bisa mata pelajaran tertentu misalnya Matematika, Nahwu Shorof, Bahasa Arab dan sebagainya tergntung dari mata pelajaran yang tidak disenangu. Disini peran Konselor menjadi sangat krusial sebab merekalah penolong dan pengarah peserta didik agar kembali on the track, setiap konselor harus mempunyai upaya dalam menangani kasus semacam ini. Konselor harus mempunyai ketrampilan dalam menangani kasus membolos ketika jam pelajaran, jika seorang konselor tidak mempunyai ketrampilan alih-alih mau mengobati namun malah menambah masalah baru dalam kasus ini. Konselor juga dituntut untuk bergerak cepat dan tepat menuntaskan kasus semacam ini agar kasus ini tak semakin parah atau bahkan bisa berdampak anak tersebut tidak naik kelas atau bisa dikeluarkan dari sekolah

Peran dari guru BK kepada siswa yang membolos akan sukses apabila guru BK menerapkan penanganan yang tepat. Contoh dari penanganan yang tidak tepat dalam lingkungan sekolah terhadap orang yang membolos adalah dengan memarahi dan memberi skor hal ini akan membuat siswa terpojok dan malah membuat siswa takut terhadap guru BK itu sendiri dan terkadang malah membuat siswa merasa seolah-seolah tervonis atas apa yang telah dia lakukan. Hal semacam ini harusnya tidak boleh dilakukan oleh seorang konselor karena tugas dari konselor bukan untuk menjadi polisi sekolah, namun sebagai penolong terhadap siswa yang mempunyai persoalan. Konselor bisa melakukan layanan konseling individu untuk mendengar alasan dia melakukan kegiatan membolos itu sendiri dan mengajak konseli untuk menyamakan persepsi mengenai kegiatan membolos itu sendiri, dengan hal semacam ini konseli akan merasa nyaman sehingga dari konselor dan konseli bisa menyelasaikan masalah secara bersama-sama.

Kebiasaan membolos ini merupakan suatu permasalahan yang perlu ditangani dan memerlukan bimbingan guru dan konselor, seperti dikemukakan oleh Gunarsabahwa tingkah laku di sekolah yang bertahan dengan kurang pembentukan kesanggupan disiplin diri, pengendalian tingkah laku dan memerlukan bimbingan guru adalah antara lain keterlambatan, membolos, 
menentang guru, perkelahian, nyontek dan sebagainy. Menurut Gunarsa membolos adalah pergi meninggalkan sekolah tanpa alasan yang tepat pada jam pelajaran dan tidak ijin terlebih dahulu kepada pihak sekolah Perilaku membolos yang dimaksud dalam penelitian disini adalah tidak masuk sekolah tanpa alasan tertentu baik pada saat pelajaran sedang berlangsung, pada waktunya masuk kelas, dan ketika sekolah berlangsung.Membolos merupakan suatu perilaku yang melanggar norma-norma sosial, karena siswa yang membolos akan cenderung melakukan hal-hal atau perbuatan yang negatif sehingga akan merugikan masyarakat sekitarnya. Selain Kartono berpendapat bahwa membolos merupakan perilaku yang melanggar norma-norma sosial sebagai akibat dari proses pengondisian lingkungan yang buruk (Damayanti, 2013).

Berdasarkan pemaparan yang dilakukan oleh peneliti diatas tentang Peran Guru BK dalam menangani perilaku membolos siswa di MTs NU Raudlatus Shibyan, Kabupaten kudus.Peneliti merumuskan tentang bagaimana upaya yang dilakukan oleh guru BK dalam menghadapi murid yang membolos, mengetahui faktor faktor yang mendorong siswa untuk melakukan perilaku membolos, juga akibat dari perilaku membolos itu sendiri terhadap siswa di MTs NU Raudlatus Shibyan Kabupaten Kudus. Tujuan akhir dari penelitian yang dilaksanakan ini adalah dapat mendiskripsikan tentang Peran Guru BK dalam menangani siswa yang membolos, mengetahui faktor dari perilaku membolos siswa serta akibat siswa dari perilaku membolos di MTs NU Raudlatus Shibyan.Penelitian ini diharapkan bisa bermanfaat untuk guru BK dalam memberikan layanan kepada siswa atau konseli.

Maka dari itu peneliti ingin mengangkat judul "Peran Guru BK Dalam Menangani Prilaku Membolos Siswa Di MTs NU Raudlatus Shibyan" dikarenakan berangkat dari rasa keprihatinan terhadap prilaku membolos yang kerap kali masih terjadi di lingkungan sekolah di semua tingkatan. Disini peneliti merasa penasaran akan Peran Guru BK menangani kasus semacam ini, seberapa efektifkan pendekatan guru BK sehingga mampu mengurangi atau bahkan menghilangkan 
angka membolos di sekolah. Namun disisi lain ternyata masih banyak guru BK yang belum paham akan penanganan kasus semacam ini, sehingga malah memperparah keadaan siswa itu sendiri. Oleh karena itu penulis ingin lebih dalam membahas judul tersebut agar dapat bermanfaat bagi semua orang termasuk, diri saya pribadi guru, sekolah dan siswa. Semoga dapat dijadikan sebagai bahan masukan bagi sekolah dan guruBK nantinya dapat digunakan sebagai bahan antisispasi dalam memberikan bantuan kepada siwa khususnya dalam masalah mengurangi keinginan berperilaku membolos pada siswa. Karena hal ini dapat merugikan diri sendiri dan orang lain serta berpengaruh terhadap nilai akademik disekolah.

\section{B. Pembahasan}

\section{Membolos Bagi Siswa}

Membolos sekolah merupakan siswa yang tidak masuk kedalam kelas untuk mengikuti kegiatan pembelajaran baik satu mapel ataupun seharian penuh. Definisi lebih mengarah kepada kondisi dimana pelajar dengan sengaja tidak masuk kedalam kelas dan tidak mengikuti pelajaran pada waktu itu. Kata "bolos" sangat terkenal di segmen pelajar baik di sekolah dasar sampai menengah. Dari beberapa survei yang dilakukan jumlah peserta didik yang melakukan perilaku membolos lebih sedikit dari pada siswa yang tidak membolos, terlepas dari besar kecilnya jumlah peserta didik yang membolos tetap harus menjadi perhatian dari sekolah, karena apabila pihak sekolah skeptis, besar kemungkinan jumlah yang membolos akan terus bertambah dan seolah-olah menjadi sebuah bola salju liar yang selalu menggelinding.

Kegiatan membolos bukanlah hal yang baru terlebih bagi para pelajar. Apalagi bagi mereka yang sebelumnya pernah mengenyam pendidikan, hal ini di karenakan perilaku membolos ini sudah ada sejak dulu dan seolah-olah menjadi perilaku warisan, tindakan semacam ini dianggap sebagai sebuah jawaban akan kejenuhan yang seringkali dialami oleh peserta didik terhadap 
sistem yang ada didalam sekolah, kejadian semacam ini seakan mencoreng isntitusi sekolah itu sendiri.

Bolos sekolah pada dasarnya adalah kegiatan tidak konsekuen terhadap tujuan pendidikan di sekolah. Tugas Pokok seorang pelajar tidak dilakukan, ada kecenderungan dalam diri siswa yang muncul adalah merasa aman karena perilaku semacam ini dilakukan oleh banyak orang, ketika dilakukan oleh banyak orang seolah-olah perilaku semacam ini adalah sebuahhal yang lumrah dan dapat di maklumi, padahal kekeliruan ataupun kebenaran yangada pada setiap diri individu, tidak bergantung dilakukan banyak orang atau sedikit orang.

Membolos juga merupakan tindakan negative yang sering dilakukan siswa didalam kegiatan pendidikan dan terdapat pada semua jenjang. Perilaku juga merupakan salah satu faktor penentu efektif dan tidaknya sikap serta tindakan seseorang dalam kehidupan bermasyarakat. Hal ini sebagai dampak dari kodrat manusia sebagai mahluk social yang selalu berinteraksi dengan orang lain (masyarkat) dan lingkungan.

Mencermati hal diatas maka perilaku adalah faktor determian menjadi penggerak arah tindakan serta perbuatan dari seseorang. Perilaku manusia juga merupakan informasi dan fungsi antara pesan dari individu dengan lingkungannya. Nawawi berpendapat bahwa sifat-sifat watak, khas, kecerdasan, khas, minat dan kecenderungan, serta perhatian sebagai individu.Sedangkan Riyadi berpendapat dalam rangka mengobati perilaku memboloss, siswa, orang tua maupun guru sebaiknya terus melakukan evaluasi, mengajak peserta didik untuk berdiskusi merupakan faktor yang sangat krusial yang harus mulai dibangun oleh orang tua yang bertujuan untuk memfilter pengaruh negatif yang dapat menyeret setiap anak.(Suparno, 2015: 51)

Perilaku membolos sudah merupakan hal yang sangat umum yang dilakukan oleh siswa jaman sekarang. Hal ini dapat terjadi dikarenakan siswa 
tidak memahami status sebagai seorang siswaserta kurang memahami akan tujuan hidupnya.Membolos sekolah pada dasarnya bukan hanya karena kenakalan peserta didik, namun juga dapat dikarenakan mereka belum mengerti terhadap tugasnya sebagai seorang siswa dan dampak yang akan diperoleh dari perilaku yang sering dibuatnya jika dia terus membolos.

Guru bimbingan dan konseling yang selama ini diasumsikan sebagai seorang yang dapat membantu mengatasi masalah pribadi yang dialami peserta didik, guru BK sangat berperan dalam memberi berbagai solusi yang tepat kepada peserta didik.Masalah yang biasanya dihadapi oleh guru BK berkisar pada problem pendidikan terlebih lagi masalah seperti kedisiplinan siswa yang kerap kali menjadi masalah utama yang harus segera ditangani oleh guru BK. Kesalahan yang masif dilakukan oleh siswa biasanya adalah melanggar tata tertib sekolah dan kebijakan sekolah. Misal pelanggaran tentang atribut sekolah, terlambat ketika masuk sekolah.Menurut Gunawan hal semacam ini biasanya dilimpahkan kepada guru BK. Seperti halnya fungsi dari bimbingan dan konseling yang membantu tiap individu untuk mengahadapi lingkungan.Karena disini tugas seorang konselor adalah untuk menjadi mitra klien sebagai penyaluran perasaan atau sebagai pemberi semangat ketika patah yang bertujuan untuk membuat utuh kembali pribadinya yang sedang tergoncang. Sedangkan Sarwono berpendapat bahwa hal tersebut menggambarkan bahwa guru Bimbingan Konseling berperan dalam proses pendidikan kedisiplinan untuk anak di sekolah, sehingga tugas yang dibebankan kepadanya sangatlah penting demi kebelangsungan siswa disekolah. Karena kedisiplinan di sekolah merupakan modal utama bagi siswa di luar sekolah. Sebagai siswa disiplin merupakan hal utama yang harus dimiliki dalam proses belajar mengajar. Dengan berdisiplin siswa akan dengan mudah menggapai aspek-aspek di sekolah. Maka peran guru Bimbingan Konseling sangatlah diperlukan.Dari uraian di atas maka dapat diambil kesimpulan bahwa, antara peran guru bimbingan konseling sebagai tokoh 
utama dalam kedisiplinan siswa memiliki peran yang sangat penting untuk mencapai tujuan yang dicita-citakan.

\section{Ciri-ciri Perilaku Bolos}

Seseorang yang melakukan penyimpangan umumnya disebut tindakan yang melanggar aturan. Tindakan menyimpang ini tergolong untuk mendapatkan sesuatu. Banyak orang yang percaya bahwa melakukan penyimpangan (atau orang yang pertama kali melakukan penyimpangan), dengan sengaja dan penuh kesadaran atau kurang sadar karena ada motifmotif tertentu. Akan tetapi, di masyarakat ada pula yang melakukan penyimpangan secara tidak sengaja, bukan berarti tidak mentaati norma yang berlaku, melainkan dapat disebabkan keterpaksaan, ketelodoran atau ketidaktahuan.(Waluya, 2007: 88)

Dengan ciri-ciri perilaku ini jelas bahwa perilaku yang negatif itu dapat dilihat pada perilaku membolos siswa, kalau di kaji banyak rinciannya diantaranya antara lain: 1) Berhari-hari tidak masuk kelas, Siswa seringkali tidak masuk kelas dikarenakan tugas-tugas sekolah yang belum mereka kerjakan dan lebih suka menghabiskan waktu di luar sekolah. 2) Tidak masuk kelas tanpa ijin, siswa selalu keluar masuk tanpa ijin di kelas dikarenakan siswa bosan dengan mata pelajaran yang mereka ikuti terlhat jelas bahwa siswa lebih senang menghabiskan waktunya di luar kelas pada saat mata pelajaran berlangsung. 3) Sering keluar pada pelajar tertentu, siswa merasa bosan di kelas pada mata pelajaran tertentu itu dikarenakan siswa merasa mata pelajaran tersebut kurang menantang baginya atau siswa merasa sulit memahami mata pelajaran tersebut sehingga lebih memilih sering keluar kelas. 4) Tidak masuk kelas setelah jam istirahat, siswa lebih memilih untuk tetap di luar kelas karena siswa ingin merasa bebas dan malas untuk mengikuti mata pelajaran berikutnya di akibatkan bosan dengan aktifitas belajar yang begitu-begitu terus. 5) Tidak tepat waktu masuk kelas (terlambat), Siswa seringkali terlambat di akibatkan mencari perhatian agar 
dapat diperhatikan. 6) Keluar masuk kelas tanpa izin, siswa melakukan hal itu karena siswa merasa guru kurang memerhatikannya. 7) Berpura-pura sakit, Siswa seringkali berpura-pura sakit agar angka absennya tidak menonjol sehingga guru dapat mempercayainya.

\section{Faktor yang mempengaruhi siswa membolos.}

Setelah mengetahui ciri-ciri perilaku siswa bolos, jelas bahwa perilaku tersebut termaksud para perilaku negatif yang harus dihilangkan agar perilaku tersebut termaksud pada perilaku negative yang harus dihilangkan agar perilaku tersebut tidak terulang-ulang, karena perilaku tersebut timbul karena ada faktor-faktor pendukung sehingga siswa tersebut membolos.

1) Faktor internal, faktor yang berasal dari dalam diri siswa seperti perilaku dan kebiasaan siswa yang memang tidak suka belajar, sekolah hanya dijadikan tempat mangkal karena kalau di rumah nanti disuruh kerja dan tidak dapat jajan di sekolah. Faktor lain dari diri sendiri yaitu, motivasi belajar atau minat akademik siswa, kondisi ketinggalan pelajaran atau karena kenakalalan remaja, konsumsi alkohol atau minuman keras.Siswa tidak memiliki motivasi belajar. Siswa sepertinya tidak ada dorongan untuk maju entah bercita-cita menjadi apa, sehingga ia tidak merasa perlu untuk sekolah secara baik.

2) Faktor eksternal berasal dari luar, biasanya dipengaruhi oleh teman yang suka bolos. Hal ini bisa terjadi misalnya karena ia punya temen yang suka bolos dan bermain seperti di taman, internet dan lain-lain. Selain itu merasa tidak mampu mengikuti pelajaran di sekolah, siswa merasa tidak mampu menguasai pelajaran-pelajaran tertentu sehingga dapat menyebabkan dia malas belajar dan melakukan perilaku bolos. Tidak mengerjakan PR yang diberikan juga mempengaruhi siswa untuk membolos, artinya bahwa siswa tersebut merasa masih mempunyai tanggung jawab yang belum dia selesaikan sehingga dia takut untuk masuk ke dalam kelas karena dia mempunyai asumsi akan dimarahi oleh guru. 
Peraturan sekolah yang longgar akan membuat siswa seenaknya dalam melakukan tindakan membolos karena merasa tidak ada tindak lanjut dari sekolahan ketika melakukan kegiatan tersebut. Selain itu suasana belajar tidak menarik membuat siswa kurang memperhatikan pelajaran yang disampaikan oleh guru.Kadangkala ada guru yang tak mampu menahan emosi karena pelanggaran yang berulang-ulang dilakukan oleh siswa sehingga hukuman yang diberikan melebihi apa yang seharusnya.

3) Faktor sekolah, sangat beresiko dalam meningkatkan perilaku membolos pada siswa diantaranya adalah ; minimnya interkasi pihak sekolah dengan orang tua siswa, peraturan mengenai membolos kurang tegas, tidak ada dukungan dari guru dan lain sebagainya

4) Faktor keluarga, meliputi pola asuh orang tua, kurangnya partisipasi orang tua dalam pendidikan anak.

Dini Hidayati mengatakan penyebab siswa membolos, dapat dipengaruhi oleh dua faktor, yaitu faktor internal dan eksternal. Faktor internal: faktor yang berasal dari dalam diri siswa bisa berupa karakter siswa yang memang suka membolos, sekolah hanya dijadikan tempat mangkal dari rutinitas-rutinitas yang membosankan di rumah. Sementara faktor eksternal: faktor yang dipengaruhi dari luar siswa, misalnya kebijakan sekolah yang tidak berdamai dengan kepentingan siswa, guru yang tidak profesional, fasilitas penunjang sekolah misal laboratorium dan perpustakaan yang tidak memadai, bisa juga kurikulum yang kurang bersahabat sehingga mempengaruhi proses belajar di sekolah.

\section{Metode}

Penelitian dilakukan di sekolahan yang terletak di desa peganjaran Kecamatan Bae yaitu di MTs NU Raudlatus Shibyan Kudus. Penelitian ini membahas tentang Peran Guru BK dalam mengatasi perilaku membolos siswa. Berdasar uraian pada permasalahan yang terdapat dalam peneltian ini 
menggunakan deskriptif kualitatif dalam pengambilan data. Demi mendapatkan data yang akurat peneliti terjun langsung kelapangan dan berbaur dengan subyek yang akan diteliti. Penelitian ini menggunakan penelitian kualitatif dengan tujuan untuk memhami secara mendalam obyek yang diteliti.Alasan lain peneliti memilih menggunakan metode kualitatif adalah karena memudahkan pembaca supaya bisa memahami dan mengerti terhadap penelitian yang disajikan, karena didalam penelitian ini disajikan bentuk kata-kata agar mudah dipahami dari pada menggunakan angka-angka.

Dalam penelitian yang dilakukan di MTs NU Raudlatus Shibyan tidak bermaksud untuk memanipulasi data yang diambil dari lapangan yang alami dan langsung dari sumber yang diteliti. Pada penelitian jenis ini adalah dengan menggunakan studi kasus,studi kasus adalah metode penelitian tentang ilmuilmu sosial, yang secara secara garis besar studi kasus merupakan strategi yang sangat pas apabila pokok pertanyaan dalam suatu penelitian berkaitan dengan why atau how, apabila peneliti hanya mendapatkan sedikit peluang dalam mengontrol rangkain peristiwa yang akan diteliti maka studi kasus sangat baik menggunakan metode penelitian kualitatif.

Alasan peneliti dalam menggunakan studi kasus semacam ini dikarenakan obyek yang harus diamati merupakan kasus yang melibatkan serta memfokuskan penelitian kepada guru BK di MTs NU Raudlatus Shibyan, diharapkan bisa mendeskripsikan secara lengkap tentang "Peran Guru BK dalam menangani perilaku membolos siswa di MTs NU Raudlatus Shibyan". Tehnik pengumpulan data ada tiga cara yakni dengan wawancara, dokumentasi dan observasi .Analisa data yang dilakukan berisfat induktif yakni digunakan dalam menyempurnakan pemahaman pada data yang diperoleh. Untuk menganalisa data bisa menggunakan cara menelaah data, menyusun satuan data, mengategorikan, reduksi dan menafsirkan. 


\section{Hasil}

Setelah melakukan kegiatan peneletian di MTs NU Raudlatus Shibyan Kudus, dengan mengumpulkan beberapa data dari hasil observasi dan wawancara bersama guru bimbingan konseling memperoleh data sebagai berikut: Pertama, peran guru BK MTs NU Raudlatus Shibyan dalam menangani perilaku membolos siswa adalah peranGuru BK sangat krusial dalam menangani perilaku membolos siswa yang kerap kali menjadi masalah, guru BK selalumemberi solusi yang tepat kepada siswanya.Masalah yang sering dihadapi oleh guru BK di MTs NU Raudlatus Shibyan seputar pada masalah kependidikan seperti kedisiplinan yang menjadi masalah utama yang segera ditangani oleh guru BK. Kesalahan yang selalu dilakukan oleh siswa di MTs NU Raudlatus Shibyan adalah sering melanggar tata tertib sekolah. Misal pelanggaran tentang atribut yang kurang lengkap, terlambat masuk sekolah. Hal hal semacam ini sering kali di limpahkan kepada guru BK.

Kedua, perilaku membolos di madrasah tersebut kebanyakan siswa kelas VIII, dapat dilihat dengan adanya siswa yang tidak masuk kelas setiap hari, siswa tidak masuk kelas tanpa izin, sering keluar ketika jam pelajaran tertentu, tidak masuk kelas lagi setelah jam istirahat atau terlambat masuk kelas serta berpura-pura sakit agar guru memperhatikannya. Ketiga, perilaku membolos yang dilakukan oleh siswa dilatar belakangi oleh faktor internal dan eksternal. faktor internal yang melatar belakangi perilaku siswa membolos yaitu sering kali malas mengikuti jam pelajaran di kelas, tidak suka pada mata pelajaran tertentu dan tidak suka pada guru mata pelajaran tersebut. Sedangkan faktor eksternal yang melatar belakangi perilaku siswa membolos yaitu peraturan sekolah yang longgar sehingga membuat siswa melakukan kegiatan atau perilaku membolos. Selain itu adanya jasa penitipan sepeda motor di belakang sekolah sehingga mempermudah akses siswa dalam melakukan tindakan membolos serta adanya pengaruh dan ajakan dari teman untuk melaksanakan perilaku membolos. 
Keempat, usaha yang dilakukan oleh guru BK dalam menangani perilaku membolos di MTs NU Raudlatus Shibyan, biasanya dengan melalui cara pendekatan konseling individu agar siswa yang melakukan perilaku membolos mau menerima arahan dari guru BK dengan suka rela. Namun jika siswa tetap bersikap tertutup dan tidak mau menceritakan tentang alasan mengapa dia membolos, guru BK bisa menggunakan cara yang lain yaitu dengan menanyakan permasalahannya pada teman dekatnya. Begitu semua informasi yang diperlukan telah diperoleh, guru BK langsung mengambil tindakan preventif dan kuratif. Dengan cara berikut:

a. Dengan Mengetahui Faktor-Faktor Penyebabnya

Dengan mengetahui faktor - faktor penyebabnya, guru BK sedikit tahu bagaimana kondisi permasalahan siswa. Langkah selanjutnya adalah melalui pendekatan agar siswa yang melakukam perilaku membolos mau menerima arahan dari guru BK. Namun jika peserta didik tetap bersikap kurang kooperatif, sama sekali tidak mau bercerita tentang permasalahan membolosnya, guru BK bisa menggunakan metode lain yakni dengan menanyakan perihal masalahnya kepada teman dekatnya.

Begitu mengambil tindakan preventif dan pengobatan. Seperti yang telah dijelaskan di atas, Memberikan nasehat ataupun arahan harus diberikan secara baik-baik karena efekny akan lebih mengena dari pada dengan bentakan ataupun dengan memarahinya. Tidak teraturnya anak masuk sekolah tidak sepenuhnya terletak pada siswa (Gunarsa, 2002: 34).

Ada banyak sebab yang terletak di luar kekuasaan anak, atau yang kurang dikuasai anak. Jadi kegiatan membolos siswa tidak sepenuhnya kesalahan siswa. Ada berbagai faktor dari luar yang turut andil dalam perilaku membolos tersebut. maka karena itu, tugas BK selain memberi arahan kepada siswa juga selalu mengkondisikan lingkungan sekolahnya sebaik dan senyaman mungkin agar siswa selalu merasa betah berada di sekolah. disamping itu guru BK juga harus selalu menjalin komunikasi yang 
baik dengan keluarga peserta didik terdapat kesepakatan dalam usaha mengatasi permasalahan anak.

b. Menerapkan Gerakan Disiplin

Gerakan disiplin ini difokuskan untuk memantau para pelajar yang membolos atau pergi pada waktu jam-jam sekolah. Biasanya mereka barada di tempat keramaian atau di tempat hiburan. Pelajar yang membolos selain merugikan dirinya sendiri juga berpotensi untuk menimbulkan keresahan di masyarakat karena biasanya pelajar yang suka membolos mempunyai tingkat kenakalan yang tinggi dan justru sering medekati kriminal. Sex bebas pada segmen pelajar juga muncul karena fenomena bolos sekolah dimana ketika orang tua sering tidak berada di rumah karena harus bekerja namun dimanfaatkan untuk berbuat negatif. Fenomena perilakumembolos sekolah ini pada dasarnya tidak bisa dianggap enteng oleh seorang guru BK karena inilah gerbang dari banyaknya hal tentang kerusakan moral pelajar dimulai.Karena hal semacam itu perlu tindakan yang cukup tegas dari para aparat Satpol PP untuk lebih sering melakukan kegiatan operasi agar bisa menjadi sebuah shock therapy yang mempunyai dampak efek jera bagi para pembolos serta perlu ketegasan dari pihak sekolah untuk mencegah siswanya dari tindakan bolos sekolah. Kalaupun peserta didik terpaksa keluar sekolah pada jam-jam Ketika jam pelajaran aktif haruslah mendapat ijin dari pihak sekolah dengan menggunakan surat ijin.

c. Sosialisasi Kepada Pengelola Hiburan

Pihak Dinas Pendidikan yang di bantu oleh Kesbanglinmas serta Satpol PP dan juga berkoordinasi dengan Kepolisian harus terus mensosialisasikan hal semacam ini kepada para pemilik tempat hiburan seperti rental Play Station agar tidak menerima pelanggan yang masih sekolah ketika masih jam sekolah.

Kebanyakan pelajar yang bolos sekolah "bersembunyi" di sana. Setelah sosialisasi dirasa cukup mungkin dengan penempelan stiker atau poster 
tentang larangan pelajar bermain di waktu jam sekolah maka ditingkatkan menjadi taraf pemantauan. Naimun jika pihak dari pemilik masih tetap membiarkan siswa membolos bermain game di tempatnya maka dapat diberi sebuah peringatan, jika peringatan yang diberikan tidak dihiraukan maka dapat juga dilakukan penyegelan yang bersifat sementara atau yang paling parah dapat dilakukan penutupan secara paksa.

Dampak buruk dari perilaku membolos apabila tidak ditangani secara cepat oleh guru BK maka akan timbul banyak damppak-dampak negatif yang merugikan peserta didik itu sendiri. Supriyo berpendapat bahwa seandainya orang tua tidak tahu tentang dampak dari membolos maka anak dapat berkelompok dengan teman-teman yang sama dan membutuhkan kelompok yang dapat menjurus ke dalam hal-hal yang negatif,obat-obat keras,ganja,peminum dan lain-lain Dan akibat yang terburuk adalah ketika anak mulai mengalami gangguan dalam perkembangannya dan dalam fase untuk menemukan identitas dirinya. Menurut Prayitno perilaku membolos dapat memunculkan dampak dampak buruk antara lain yaitu;(a) Minat berkurang terhadap pelajaran-pelajaran,dampak yang pertama dari perilaku membolos adalah minat terhadap pelajaran akan berkurang drastis, (b)Gagal ketika ujian, orang yang senang membolos akan kehilangan minat belajar dan ketika ujian dia akan mengalami kegagalan, (c) Hasil belajar yang dia dapat tidak selaras dengan potensi yang dia milki, dampak ketiga dari membolos adalah siswa akan mendapati hasil belajar yang tidak sesuai dengan kemampuan yang dia miliki padahal sebelum melakukan perilaku membolos hasil belajarnya cenderung bagus, (d) Tidak dapat naik kelas, siswa yang gemar membolos dapat tidak naik kelas karena dalam nilai akademik turun drastis serta dalam absensi sangat jelek,(e) Penguasaan terhadap materi dari mata pelajaran akan sangat tertinggal dari teman-teman lainnya, kosekuensi yang harus ditanggung oleh siswa yang membolos adalah dia selalu tertinggal akan materi yang disampaikan oleh guru hal ini dikarenakan ketika guru 
memaparkan materi di kelas dia tidak ada di kelas,(f) Dikeluarkan oleh sekolah, dampak terburuk dari seringnya membolos adalah dikeluarkan dari sekolah, sekolah melakukan ini juga bukan tanpa alasan namun melihat dari nilai akademik yang cenderung turun dan absensi di kelas yang sangat rendah.

Dari penjelasan kedua tokoh diatas maka dapat ditarik satu kesimpulan bahwa perilaku membolos merupakan sebuah perilkau yang mempunyai dampak yang sangat besar seperti kegagalan dalam belajar namun dapat berakibat tidak naik kelas atau bahkan dikeluarkan dari sekolah,tetapi hal ini bisa membawa dampak yang sangat luas seperti menjadi pecandu narkoba, menyukai tindakan kekerasan, menyukai freesex dan tindakan mengerikan lainnya.

\section{Simpulan}

Membolos adalah kegiatan pergi meninggalkan sekolah tanpa alasan yang tepat pada jam pelajaran dan tidak ijin terlebih dahulu kepada pihak sekolah. Dalam hal ini guru BK sangat berperan dalam memberi berbagai solusi yang tepat kepada peserta didik. Masalah yang biasanya dihadapi oleh Guru BK berkisar pada problem pendidikan terlebih lagi masalah seperti kedisiplinan siswa yang kerap kali menjadi masalah utama yang harus segera ditangani oleh guru BK. Kesalahan yang masif dilakukan oleh siswa biasanya adalah melanggar tata tertib sekolah dan kebijakan sekolah. Misal pelanggaran tentang membolos, atribut sekolah, terlambat ketika masuk sekolah. Terdapat beberapa ciri cirri siswa yang sering kali membolos seperti berhari-hari tidak masuk kelas, tidak masuk kelas tanpa ijin, sering keluar pada pelajar tertentu, tidak masuk kelas setelah jam istirahat, tidak tepat waktu masuk kelas (terlambat), keluar masuk kelas tanpa izin, berpura-pura sakit.

Membolos juga dipengaruhi oleh beberapa faktor diantaranya adalah faktor internal dan eksternal.Faktor internal, faktor yang berasal dari dalam diri siswa seperti perilaku dan kebiasaan siswa yang memang tidak suka belajar, sekolah 
hanya dijadikan tempat mangkal karena kalau di rumah nanti disuruh kerja dan tidak dapat jajan di sekolah. Faktor lain dari diri sendiri yaitu, motivasi belajar atau minat akademik siswa, kondisi ketinggalan pelajaran atau karena kenakalalan remaja, konsumsi alkohol atau minuman keras. Siswa tidak memiliki motivasi belajar. Siswa sepertinya tidak ada dorongan untuk maju entah bercita-cita menjadi apa, sehingga ia tidak merasa perlu untuk sekolah secara baik.

Faktor eksternal berasal dari luar, biasanya dipengaruhi oleh teman yang suka bolos. Hal ini bisa terjadi misalnya karena ia punya temen yang suka bolos dan bermain seperti di taman, internet dan lain-lain. Selain itu merasa tidak mampu mengikuti pelajaran di sekolah, siswa merasa tidak mampu menguasai pelajaran-pelajaran tertentu sehingga dapat menyebabkan dia malas belajar dan melakukan perilaku bolos. Tidak mengerjakan PR yang diberikan juga mempengaruhi siswa untuk membolos, artinya bahwa siswa tersebut merasa masih mempunyai tanggung jawab yang belum dia selesaikan sehingga dia takut untuk masuk ke dalam kelas karena dia mempunyai asumsi akan dimarahi oleh guru.

Usaha yang dilakukan oleh guru BK dalam menangani perilaku membolos, biasanya dengan melalui cara pendekatan konseling individu agar siswa yang melakukan perilaku membolos mau menerima arahan dari guru BK dengan suka rela. sedangkan jika seorang siswa masih bersikap tertutup, tidak mau menceritakan permasalahan mengapa ia membolos, maka guru BK akan menggunakan cara lain yaitu menanyakan pada teman dekatnya. Begitu semua informasi yang diperlukan telah diperoleh, guru BK langsung mengambil tindakan preventif dan kuratif. Perilaku membolos dapat memunculkan dampak dampak buruk antara lain Minat berkurang terhadap pelajaran-pelajaran, gagal ketika ujian,Hasil belajar yang dia dapat tidak selaras dengan potensi yang dia milki, tidak dapat naik kelas, penguasaan terhadap materi dari mata pelajaran akan sangat tertinggal dari teman-teman lainnya,dan yang paling parah adalah dikeluarkan oleh sekolah. 


\section{DAFTAR PUSTAKA}

Damayanti, F. A. (2013). Studi tentang perilaku Membolos pada Siswa SMA Swasta di Surabaya. Jurnal BK UNESA, 3 (1).

Gunarsa, S. (2002). Psikologi Untuk Membimbing. BPK Gunung Mulia.

Suparno, P. (2015). Pendidikan budi pekerti di Sekolah: Suatu Tinjauan Umum. Dee Publishing.

Waluya, B. (2007). Sosiologi: Menyelami Fenomena Sosial Di Masyarakat untuk SMA/MA kelas X. Setia Purna Inves. 